\title{
A study on trypsin, Aspergillus flavus and Bacillus sp. protease inhibitory activity in Cassia tora (L.) syn Senna tora (L.) Roxb. seed extract
}

\author{
Vinayak R Tripathi, Shailendra Kumar and Satyendra K Garg ${ }^{*}$
}

\begin{abstract}
Background: Proteases play an important role in virulence of many human, plant and insect pathogens. The proteinaceous protease inhibitors of plant origin have been reported widely from many plant species. The inhibitors may potentially be used for multiple therapeutic applications in viral, bacterial, fungal diseases and physiological disorders. In traditional Indian medicine system, Cassia tora (Senna tora) is reportedly effective in treatment of skin and gastrointestinal disorders. The present study explores the protease inhibitory activity of the above plant seeds against trypsin, Aspergillus flavus and Bacillus sp. proteases.

Methods: The crushed seeds of Cassia tora were washed thoroughly with acetone and hexane for depigmentation and defatting. The proteins were fractionated by ammonium sulphate (0-30, 30-60, 60-90\%) followed by dialysis and size exclusion chromatography (SEC). The inhibitory potential of crude seed extract and most active dialyzed fraction against trypsin and proteases was established by spot test using unprocessed $x$-ray film and casein digestion methods, respectively. Electrophoretic analysis of most active fraction (30-60\%) and SEC elutes were carried employing Sodium dodecyl sulphate polyacrylamide gel electrophoresis (SDS-PAGE) and Gelatin SDS-PAGE. Inhibition of fungal spore germination was studied in the presence of dialyzed active inhibitor fraction. Standard deviation (SD) and ANOVA were employed as statistical tools.
\end{abstract}

Results: The crude seeds' extract displayed strong antitryptic, bacterial and fungal protease inhibitory activity on $x$ ray film. The seed protein fraction $30-60 \%$ was found most active for trypsin inhibition in caseinolytic assay $(\mathrm{P}<$ 0.001). The inhibition of caseinolytic activity of the proteases increased with increasing ratio of seed extract. The residual activity of trypsin, Aspergillus flavus and Bacillus sp. proteases remained only 4, 7 and 3.1\%, respectively when proteases were incubated with $3 \mathrm{mg} \mathrm{ml}^{-1}$ seed protein extract for $60 \mathrm{~min}$. The inhibitory activity was evident in gelatin SDS-PAGE where a major band ( 17-19 kD) of protease inhibitor (PI) was detected in dialyzed and SEC elute. The conidial germination of Aspergillus flavus was moderately inhibited (30\%) by the dialyzed seed extract.

Conclusions: Cassia tora seed extract has strong protease inhibitory activity against trypsin, Aspergillus flavus and Bacillus sp. proteases. The inhibitor in Cassia tora may attenuate microbial proteases and also might be used as phytoprotecting agent.

\section{Background}

Proteases constitute one of the largest functional group of proteins involved in many normal and pathological processes. Protease inhibition of pathogenic organisms may aid in control of several diseases [1]. Plants are known to synthesize self-protective compounds as well

\footnotetext{
* Correspondence: sk_garg001@yahoo.com

Centre of Excellence in Microbiology, Dr. Ram Manohar Lohia Avadh University, Faizabad-224001, Uttar Pradesh, India
}

as accumulate inducible proteins that can directly affect microbes [2]. A number of such antifungal and antibacterial proteins include lectins, ribosomal inactivating proteins, zeamatin, chitinases, glucanases, thionins and protease inhibitors [2]. Recently, inhibitors of proteases have shown promise in their emergence as alternative approach in antiviral, antibacterial to anticarcinogenic treatments $[1,3]$. The advent of recent biotechnological and pharmaceutical approaches envisages application of protease inhibitors to contain plant and human diseases.

\section{() Biomed Central}

C 2011 Tripathi et al; licensee BioMed Central Ltd. This is an Open Access article distributed under the terms of the Creative Commons Attribution License (http://creativecommons.org/licenses/by/2.0), which permits unrestricted use, distribution, and reproduction in any medium, provided the original work is properly cited. 
Traditional Indian medicinal system emphasizes the use of plants and herbs for many maladies. Most of these are used without much knowledge about their active constituents and mechanism of action. Cassia tora (Senna tora), a member of Leguminosae (subfamily Caesalpinoideae), is found as weed throughout the India. The herb is reportedly beneficial in skin diseases, possesses anthelmintic properties and at times recommended in liver complaints and gastrointestinal disorders [4].

Proteinaceous protease inhibitors are important defense molecules expressed in various plants, animals and microbes [5]. The evidence of protease inhibitors' involvement in plant defense was demonstrated as early in 1947 by Mickel and Standish, when they observed that the larvae of certain insects were unable to develop normally on soybean products [6]. Subsequently, the trypsin inhibitors present in soybean were shown to be toxic to the larvae of flour beetle, Tribolium confusum [7]. These findings were further substantiated by expression of the cowpea trypsin inhibitor gene in tobacco, which increased its resistance against herbivorous insects [8]. The plant protease inhibitors are generally small proteins, which regulate significant physiological processes, and are also induced upon attack by insects or pathogens [9]. Protease inhibitors exhibit a peculiar property of forming complexes with proteolytic enzymes and promote inhibition of their activity by competing for the catalytic site. Majority of proteinase inhibitors studied in plant kingdom originate from three main families namely leguminosae, solanaceae and gramineae [10].

Aspergillus sp. is a causative agent of different diseases of plants, humans, insects and other organisms [11]. Aspergilli are commonly considered as opportunistic pathogens. Aspergillus flavus is a unique species as it has wide host range from humans, plants, insects to animals, and produces one of the potentially harmful aflatoxins. Aflatoxins are mycotoxins produced as secondary metabolites by aspergilli and not known to have any specific biological role in these organisms [12]. It is widely distributed in tropical and subtropical zones around the globe. Aspergillus flavus isolates obtained from cottonseed, corn, peanut, insect and human display proteinase activity to various extents [13]. They secrete variety of proteinases but major appears to be serine and metalloproteinases [14]. On account of aflatoxin B1 production, it assumed significant agricultural importance. Crops affected by aflatoxins include cotton, peanut, tree nut, corn (maize), rice, pepper, figure and spices. When Aspergillus flavus infects susceptible crops, contamination with aflatoxin greatly reduces the value of the commodity [15]. They also become harmful for animals by their aflatoxins, which cause mortality and reduced productivity in farm animals.
The aflatoxins are detrimental to humans, as high concentrations have been associated with liver cancer [12]. Further, Aspergillus flavus has been associated with secondary respiratory infections in immuno-compromised patients. Aspergillus flavus is considered to be second leading cause of invasive aspergillosis [16].

Bacillus species is widely distributed in nature. It has been reported from nosocomial environments as well as from soil, water and air. Normally they are considered avirulent, but three species such as Bacillus cereus, Bacillus anthracis and Bacillus thuringiensis have received wide attention [17]. While Bacillus anthracis is responsible for anthrax, Bacillus thuringiensis is known for its insecticidal toxins. Bacillus cereus is reported in food poisoning, and more severely for endopthalamitis, meningoencephalitis and infection in immunocompromised patients [17-20]. The proteases along with enterotoxins, emetic toxin (cereulide), hemolysins and phoshpolipase $\mathrm{C}$ as well as other enzymes like $\beta$-lactamases and collagenases from Bacillus sp. are known potential virulence factors [21].

In the present study, protease inhibitory activity of Cassia tora seed extract has been investigated against trypsin and proteases of Bacillus sp. isolate and pathogenic fungus Aspergillus flavus employing spot test method using unprocessed $x$-ray film and caseinolytic assay. Electrophoretic (SDS and Gelatin- SDS PAGE) analysis is carried out to confirm the hitherto unreported trypsin resistant proteinaceous protease inhibitory activity in seed. Effect of seed extract on Aspergillus flavus spore germination has also been studied.

\section{Methods}

\section{Plant material and extraction of protease inhibitor (PI)}

The Cassia tora seeds were collected from fields of Faizabad region (UP, India) during November 2008 to January 2009. The plant seeds were identified as Cassia tora L. Syn. Senna tora (L.) Roxb. and deposited at Raw Materials Herbarium \& Museum, NISCAIR, New Delhi (specimen reference number 1729/29). The seed extract was prepared as per the method described by Mulimani et al. [22]. Briefly, 100 gram dry seeds of Cassia tora were finely powdered, depigmented and defatted with 3 volumes of chilled acetone washing and allowed to air dry. Further washing was carried out with 2 volumes of chilled hexane. After complete air drying, the seed powder was soaked overnight in $100 \mathrm{mM}$ sodium phosphate buffer ( $\mathrm{pH}$ 7.1) at $4{ }^{\circ} \mathrm{C}$ (containing $1 \%$ polyvinyl pyrrolidine for effective removal of phenols). The suspension was centrifuged at $12,000 \mathrm{~g}$ for $20 \mathrm{~min}$ at $4^{\circ} \mathrm{C}$. The supernatant was used as a source of crude plant extract. Further, supernatant was saturated with ammonium sulphate in three stages, i.e., 0 $-30 \%, 30-60 \%$ and $60-90 \%$ for precipitation of proteins present. Protein pellet obtained in each step was dissolved 
in minimum volume of $100 \mathrm{mM}$ sodium phosphate buffer (pH 7.1), and dialyzed extensively against water using 12 $\mathrm{kD}$ membrane (Sigma chemicals) for $24 \mathrm{~h}$. For inhibitory activity analyses, the seeds' endoproteolytic and protease inhibitory activity were inactivated by heating at optimized $55^{\circ} \mathrm{C}$ for $15 \mathrm{~min}$ and $100^{\circ} \mathrm{C}$ for $60 \mathrm{~min}$, respectively.

Each dialyzed fraction was analyzed using caseinolytic method [23] for its PI activity and $500 \mu \mathrm{l}$ of most active fraction (30-60\%) was subjected to size exclusion chromatography using Sephadex G-75 (Sigma chemicals) gel filtration column $(20 \times 300 \mathrm{~mm})$. Prewashing of column was done with $100 \mathrm{ml}$ of the Tris- $\mathrm{HCl}$ buffer ( $\mathrm{pH} 8.0$, $50 \mathrm{mM}$ ). The proteins were eluted in $2 \mathrm{ml}$ fractions using same buffer and each fraction was analyzed at 280 $\mathrm{nm}$ to detect the presence of proteins. The protein was quantified as per Lowry et al. [24]. Activity of each fraction was estimated and active fractions were pooled [23].

\section{Proteases of bacterial, fungal and animal origin}

A bacterium was isolated from the local district hospital ward, and identified as Bacillus sp. employing cultural and biochemical characteristics as per the Bergey's Manual of Systematic Bacteriology [25]. It was grown in modified Glucose Yeast Extract (GYE) broth containing $\left(\mathrm{gl}^{-1}\right.$ distilled water): glucose, 10.0; peptone, 10.0; yeast extract, 5.0 and $\mathrm{NaCl}, 5.0$ [26]. For protease production, a loopful culture was inoculated in $100 \mathrm{ml}$ modified GYE broth ( $\mathrm{pH} 9$; adjusted using sterilized $1 \mathrm{M} \mathrm{Na}_{2} \mathrm{CO}_{3}$ solution after autoclaving) in Erlenmeyer flasks and incubated at $37 \pm 1^{\circ} \mathrm{C}$ on incubator shaker (150 rpm) for $20 \mathrm{~h}$. After incubation, culture broth was centrifuged at $16,000 \mathrm{~g}$ $\left(4^{\circ} \mathrm{C}\right)$ for $5 \mathrm{~min}$ and cell-free supernatant was used as protease source. Aspergillus flavus (MTCC 2798) was procured from the Microbial Type Culture Collection, Institute of Microbial Technology, Chandigarh, India. The fungal culture was maintained on $5 \mathrm{~g}$ solid substrate ( $2.5 \mathrm{~g}$ wheat bran $+2.5 \mathrm{~g}$ corn cob) moistened with $10 \mathrm{ml}$ of moistening medium containing ( $\mathrm{gl}^{-1}$ distilled water): glucose, 10.0; peptone, 10.0; malt extract, 5.0 and $\mathrm{CaCl}_{2}$, 0.1 . After complete sporulation, the culture was soaked in $25 \mathrm{ml}$ sterile distilled water, filtered after $4 \mathrm{~h}$ and the filtrate was taken as a source of enzyme. Bovine trypsin (EC. 3.4.21.4) from Himedia Laboratories Pvt. Ltd., India was used directly as an animal protease.

\section{Protease assay}

The protease activity was assayed by the casein digestion method [23]. One $\mathrm{ml}$ of enzyme was incubated with 3.0 $\mathrm{ml}$ of $1 \%(\mathrm{w} / \mathrm{v})$ casein (prepared in $100 \mathrm{mM}$ Tris- $\mathrm{HCl}$ buffer; $\mathrm{pH} 8.0$ ) at $37 \pm 1^{\circ} \mathrm{C}$, and after $10 \mathrm{~min}$, the reaction was stopped by addition of $3.0 \mathrm{ml}$ of $10 \%(\mathrm{w} / \mathrm{v})$ trichloroacetic acid (TCA). The mixture was centrifuged at $16,000 \mathrm{~g}$ for $10 \mathrm{~min}$, and absorbance of supernatant was taken at $275 \mathrm{~nm}$ to estimate the released tyrosine using tyrosine as standard. One protease unit was defined as the amount of enzyme that liberates $1.0 \mu \mathrm{g}$ of tyrosine $\mathrm{min}^{-1} \mathrm{ml}^{-1}[23]$.

\section{Detection of protease inhibitory (PI) activity \\ (A) Spot-test analysis}

Twenty $\mu \mathrm{l}$ of trypsin $(5,10$ and $15 \%$, w/v in Tris- $\mathrm{HCl}$ buffer, $\mathrm{pH}$ 8.0) was spotted on to gelatin coated $\mathrm{x}$-ray film (Kodak) and incubated at $37^{\circ} \mathrm{C}$ for 30 min to observe gelatin digestion. The crude extract was diluted suitably with Tris- $\mathrm{HCl}$ buffer ( $\mathrm{pH} 8.0$ ) to get 3 different protein concentrations of 2.0, 5.0 and $12.5 \mu \mathrm{g} \mathrm{ml}^{-1}$. Each dilution was incubated with equal volume of trypsin $(10 \%, w / v)$ at $37^{\circ} \mathrm{C}$ for $60 \mathrm{~min}$ and applied on $\mathrm{x}$-ray film as described previously. The film was washed using mildly warm water to observe the extent of gelatin clearance. The seed extracts with and without buffer were spotted as controls. Similar reactions were carried out using proteases of Aspergillus flavus and Bacillus sp., instead of trypsin. Later, the presence of protease inhibitory activity of seed was confirmed using ammonium sulphate precipitated fractions and elutes of SEC.

\section{(B) Casein digestion (Caseinolytic) method}

Equal volume of ammonium sulphate fractions (0-30, 30$60,60-90 \%)$ and trypsin $(10 \%, \mathrm{w} / \mathrm{v})$ was incubated at $37^{\circ} \mathrm{C}$ for $30 \mathrm{~min}$ and residual protease activity was estimated [23]. Further, one $\mathrm{ml}$ each of different concentrations $\left(0.33,0.66,1.0,2.0,3.0 \mathrm{mg} \mathrm{ml}^{-1}\right)$ of most effective plant seed extract fraction was incubated with $1 \mathrm{ml}$ of trypsin (100 $\mathrm{g} \mathrm{m} \mathrm{ml}^{-1}, 455$ caseinolytic units), fungal protease (245 caseinolytic units) and bacterial protease (98 caseinolytic units) at $37 \pm 1^{\circ} \mathrm{C}$ for $1 \mathrm{~h}$. Following incubation, the residual protease activity of trypsin, bacterial and fungal protease was estimated as per the method described earlier [23]. The inhibition was calculated from the difference between untreated (without seed extract) and treated (with seed extract) samples divided by untreated sample reading, multiplied by 100 [27]. Protease activities of individual trypsin, fungal and bacterial proteases were taken as control. The experiment was carried out in triplicates.

\section{(C) Electrophoretic analysis}

The dialyzed 30-60\% ammonium sulphate fraction and active elutes' fraction(s) obtained from gel filtration were subjected to $15 \%$ SDS-PAGE [28]. In another set of experiment, an activity gel having gelatin $(0.1 \% \mathrm{w} / \mathrm{v})$ copolymerized with SDS-PAGE was used to analyze the PI activity [29]. The samples were not boiled prior to loading. In activity gel, after appropriate run, SDS was removed by washing the gel with triton X-100 $(50 \mathrm{ml}$, $2.5 \% \mathrm{v} / \mathrm{v}$ ) for $45 \mathrm{~min}$. The gel was washed twice with distilled water and then incubated with $100 \mathrm{ml}$ of trypsin $\left(250 \mu \mathrm{g} \mathrm{ml}^{-1}, 1137.5 \mathrm{U} \mathrm{ml}^{-1}\right.$, in $100 \mathrm{mM}$ Tris- $\mathrm{HCl}$ buffer, $\mathrm{pH} 8.0$ ) at $37^{\circ} \mathrm{C}$ for $1 \mathrm{~h}$. The gel was again washed with 
distilled water and stained using Coomassie brilliant blue R-250 stain. The active fraction was observed as distinct blue band after proper destaining.

\section{Antifungal activity assay}

The dialyzed extract (30-60\%) was used to study its effect on conidial germination of Aspergillus flavus. The seeds' extract $\left(1.8 \mathrm{mg} \mathrm{ml}^{-1}\right)$ was filtered using nitrocellulose membrane (pore size $0.22 \mu \mathrm{m}$ ), and its $50 \mu \mathrm{l}$ fraction was mixed with $100 \mu \mathrm{l}$ of potato dextrose broth (PDB) containing conidia $\left(7 \times 10^{-4}\right)$, poured in depression slide and incubated at $37^{\circ} \mathrm{C}$ for $36 \mathrm{~h}$. Heat inactivated $\left(100^{\circ} \mathrm{C}\right.$ for $\left.60 \mathrm{~min}\right)$ seed extract was used as PI control. The inhibition pattern was also confirmed using pooled active fraction obtained after SEC.

\section{Statistical analysis}

The spot test experiments were carried out thrice each in duplicate. In the caseinolytic assay analysis, standard deviation (SD) was calculated using Microsoft Excel. Further, analysis of variance (ANOVA) was performed using GraphPad InStat version 3.10.

\section{Results and Discussion}

\section{Spot-test analysis}

Trypsin produced a distinct zone of gelatin clearance (Figure 1A) on $\mathrm{x}$-ray film. After incubation with preheated plant seed extract for $1 \mathrm{~h}$, trypsin exhibited variable strength of clearance with varied seed extract dilutions. At lowest extract concentration, the inhibition was partial as evident from incomplete gelatin digestion (Figure 1B-ii). However, at increasing seed extract concentrations (5 \& $12.5 \mu \mathrm{g} \mathrm{ml}^{-1}$ ), such clearance was not evident (Figure 1Biii \&1iv), which is indicative of complete trypsin inhibition. Similar to trypsin, the culture supernatant of Aspergillus flavus (caseinolytic activity $245 \mathrm{U} \mathrm{ml}^{-1}$ ) and of Bacillus sp. (caseinolytic activity $98 \mathrm{U} \mathrm{ml}^{-1}$ ) also cleared the gelatin coated on x-ray film (Figure 1C-ii, 1D-ii). However, upon incubation with seed extract, both the supernatants were unable to clear the gelatin, thereby indicating their effective inhibition (Figure 1C-iii, 1iv \&1D-iii, iv). These results reflect presence of strong protease inhibitor(s) in Cassia tora seed extract. The seed extracts used as control did not cause gelatin digestion (Figure $1 \mathrm{C}-\mathrm{i}, 1 \mathrm{v} \& 1 \mathrm{D}-\mathrm{i}, \mathrm{v}$ ). The spot test method is a rapid and sensitive test for visual detection of protease inhibitors even in lower quantities. Cheung et al. studied the effect of soybean trypsin inhibitor mixed with trypsin on X-ray film and reported that 2 $\mu \mathrm{g} \mathrm{ml}^{-1}$ inhibitor was effective in trypsin inhibition [30]. The $\mathrm{x}$-ray film consists of acetate cellulose coated on both sides with silver halide and gelatin. Gelatin is a substrate for proteolytic enzymes, and minimum effective inhibitory concentrations reflect the sensitivity of this method.

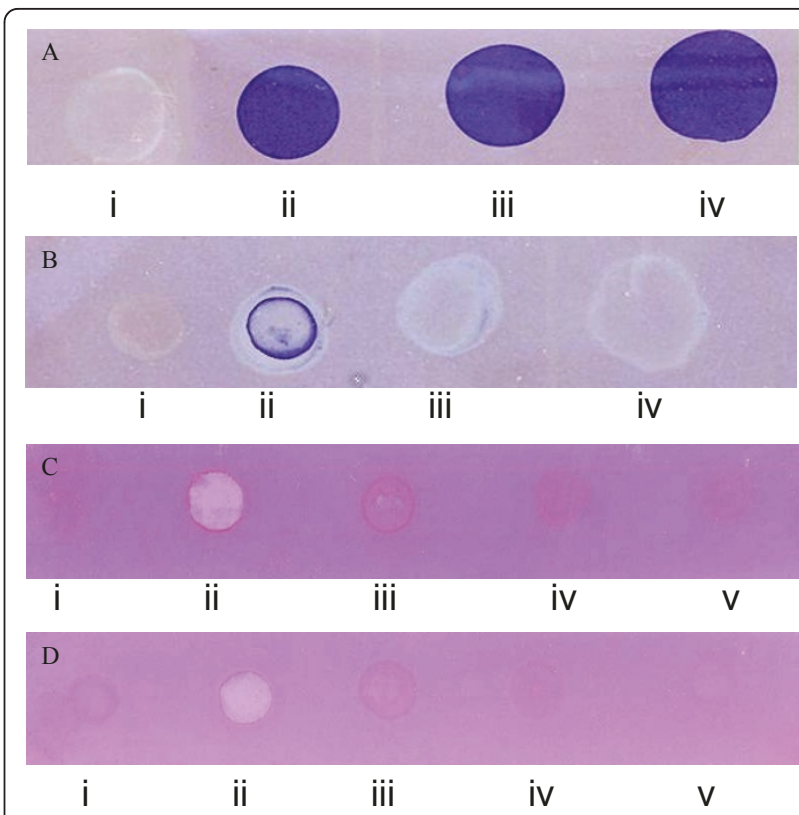

Figure 1 Detection of protease inhibitory activity using X-ray film. Trypsin (5, $10 \& 15 \%, \mathrm{w} / \mathrm{v}$ in Tris-HCl buffer) cleared the gelatin coat on film (Figure 1A-ii, iii \& iv). Buffer alone served as control (Fig. 1 A-i). Trypsin (10\%), preincubated with heat-treated crude seed extract $\left(2 \mathrm{mg} \mathrm{ml}^{-1}\right)$ for $60 \mathrm{~min}$., was moderately inhibited and partial gelatin clearance was observed (Figure $1 \mathrm{~B}$-ii). At higher concentrations $\left(5,12.5 \mathrm{\mu g} \mathrm{ml}^{-1}\right)$, trypsin was completely inhibited and no gelatin digestion was seen (Figure 1 B-iii, iv). The heattreated plant material (no endoproteolytic activity) served as control (Fig1 B-i). The inhibitory effect against Aspegillus flavus and Bacillus sp. protease is shown in Figure 1 C \& D respectively. Aspegillus flavus and Bacillus sp. protease caused gelatin digestion (Figure 1 Cii \& D-ii) which upon incubation with seed extract was not seen (Figure 1 C-iii, iv \& D-iii, iv). Buffer alone (Figure $1 C$-i), heat treated (Figure 1D -i) and inactivated seed extract (Figure 1C -v \& D -v) served as control.

The heat treatment of plant extract is critical for denaturation of endogenous thermolabile proteases as they may interfere with results. Gallagher et al. [31] have also described that endogenous protease activity of the plants can lead to artifacts in screening of inhibitors. Further, it is also established, albeit indirectly, that inhibitor fraction in Cassia tora seed extract is thermostable. Proteins involved in defense mechanism are known to be heat stable, and thermostability of seed extract for protease inhibition is apparently in consonance with report of Azarkan et al. [32]. Lopes et al. have reported a heat stable trypsin inhibitor from Acacia plumose having antifungal properties against Aspergillus niger and Fusarium moniliforme [33].

\section{Casein digestion (Caseinolytic) method}

Among all, the dialyzed $30-60 \%$ ammonium sulphate fraction exhibited maximum antitryptic activity, and was 
used for further studies (Figure 2 inset). In this fraction, the trypsin activity was progressively reduced upon incubation with increased plant seed protein extract (Figure 2). At lower concentration of protein in plant extract $\left(0.33\right.$ and $\left.0.66 \mathrm{mg} \mathrm{ml}^{-1}\right)$, the residual activity was 56 and $38 \%$, respectively, which further reduced to $10 \%$ ( $1 \mathrm{mg} \mathrm{ml}^{-1}$ seed extract). The overall inhibition of trypsin increased up to $96 \%$ at higher concentration (3 mg $\left.\mathrm{ml}^{-1}\right)$. The ANOVA revealed significant $\mathrm{P}$ value $(<0.001)$, which is indicative of strong inhibitory effect of plant extract even at low concentrations. However, Tukey-Kramer Multiple comparisons test showed less significant $\mathrm{P}$ value $(>0.05)$ between 1 and $2 \mathrm{mg} \mathrm{m}^{-1}$ seed extract and between 2 and $3 \mathrm{mg} \mathrm{ml}^{-1}$ extract. The pattern of protease inhibition in culture supernatant of Aspergillus flavus and Bacillus sp. was similar to trypsin. The caseinolytic activities of Aspergillus flavus proteases remained 35 and $26 \%$ at lower concentrations $(0.33$ and $0.66 \mathrm{mg} \mathrm{ml}^{-1}$ ). It was further reduced to $11 \%$ only at 1 $\mathrm{mg} \mathrm{ml}^{-1}$ plant protein. The Bacillus sp. protease activity was inhibited up to $65 \%$ and $91 \%$ at 0.66 and $1.0 \mathrm{mg}$ $\mathrm{ml}^{-1}$ seed extract, respectively (Figure 2 ). The $\mathrm{P}$ value $(<0.001)$ is significant for inhibitory effect of seed extract against fungal and bacterial proteases at all low concentrations. However, Tukey-Kramer Multiple comparisons test showed less significant $\mathrm{P}$ value $(>0.05)$ between higher concentrations of 1,2 and $3 \mathrm{mg} \mathrm{ml}^{-1}$ extract. In non parametric analysis of variance (KruskalWallis test), the inhibitory effect of plant extract against all proteases was significant ( $\mathrm{P}$ value 0.0162 ). The pattern of inhibition of proteolytic activity of trypsin corresponds with the findings of Pando et al. [34] and Bhattacharyya et al. [35]. Baker et al. reported an inhibitor, having limited activity against Aspergillus flavus, from maize displaying $84 \%$ trypsin inhibition comparable to that exhibited by soybean trypsin inhibitor [36]. Earlier, a maize trypsin inhibitor was reported as the basis of resistance against Aspergillus flavus infection [37].

The prevalence of Aspergillus flavus in plants, farm animals and above all in humans transforms it to a potent threat to agriculture and human health. Since strains of Aspergillus flavus lack host specialization [13], and produces virulent proteases, it leads to allergenicity (due to serine proteases), invasive aspergillosis and cutaneous infections [12]. Therefore, inhibition of their proteolytic activity is important for generalized defense response in diverse organisms.

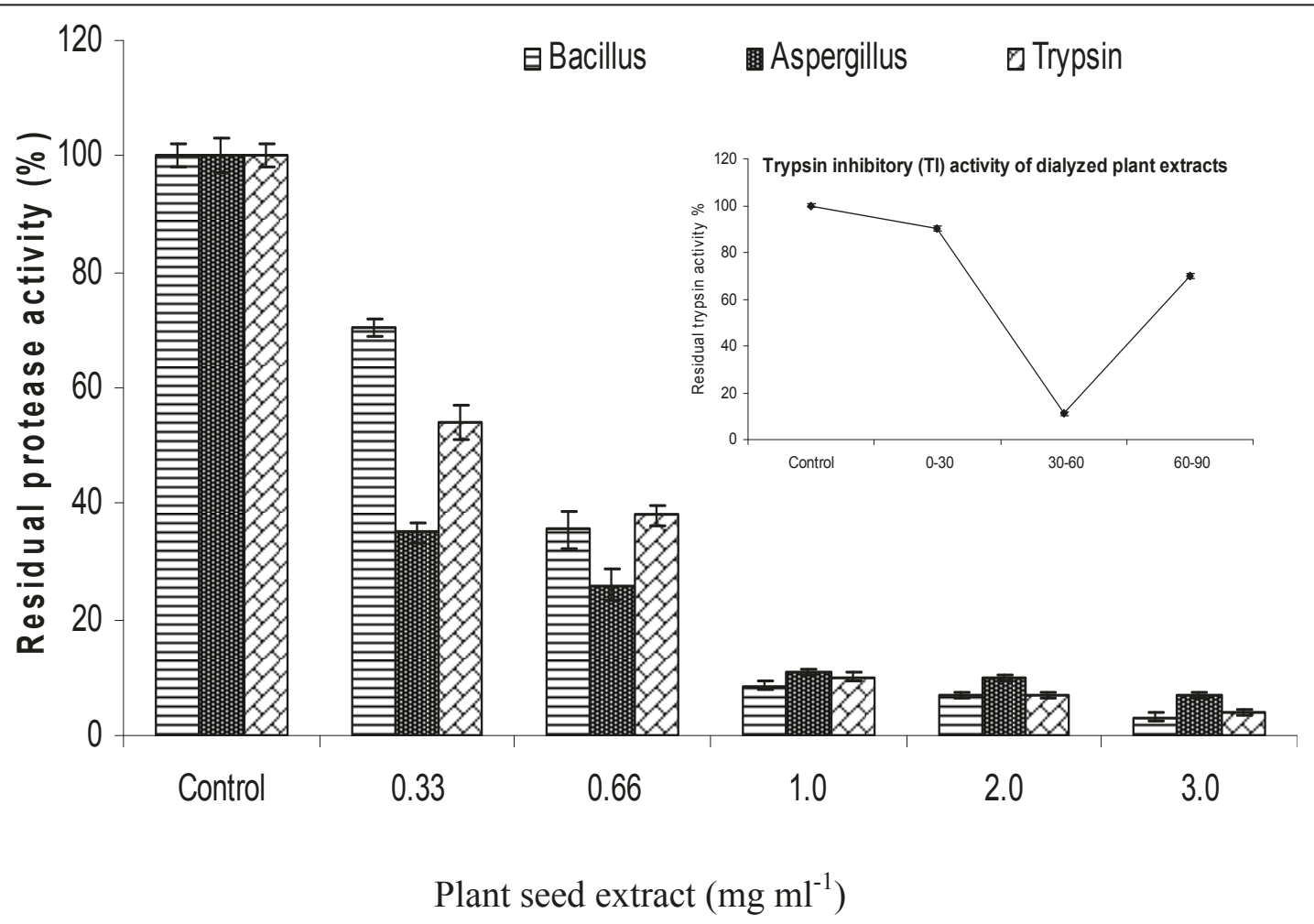

Figure 2 Residual activities of trypsin, bacterial and fungal proteases in the presence of different concentrations of dialyzed seed extract (30-60\%). One $\mathrm{ml}$ plant extract $\left(0.33,0.66,1.0,2.0\right.$ and $3.0 \mathrm{mg} \mathrm{ml}^{-1}$ ) preincubated with $1 \mathrm{ml}$ each of trypsin (455 $\mathrm{U}$ caseinolytic activity), Bacillus sp. (98 U caseinolytic activity) and Aspergillus flavus protease (214 U caseinolytic activity). Trypsin inhibitory activity pattern of different ammonium sulphate fraction is shown in Figure 2 (inset). 
Different species of Bacillus remain associated with various gastrointestinal and non-gastrointestinal infections in normal and immunocompromised individuals. The bacterium may feed on host tissues by producing toxins, phospholipases and proteases. Proteins, peptides and amino acids have been suggested as the preferred nutrient sources for Bacillus cereus [17], possibly linked to the growth of bacterium as a human and animal pathogen. Thus, proteases help in defense and survival of the organism in host cell environment. The attenuation of bacterial protease virulence employing biomolecules like protease inhibitor can be an effective strategy to combat such infections. This presumably provides competitive advantage to the host immune system, as ability of bacterial adaptation to the mammalian environment may be stressed or abolished. It is also expected that protease inhibitors unlike conventional antibiotics would not exert a selective pressure leading to development of resistance in pathogenic microorganisms [38].

\section{Electrophoretic analysis}

In the present study, the denaturing and gelatin SDSPAGE analysis revealed activity in seed extract against trypsin. Previous studies indicated the presence of most active inhibitor in 30-60\% ammonium sulphate fraction. Though, $30-60 \%$ fraction contained many other proteins (lane 1\&2, Figure 3A), they were digested upon incubation with trypsin, and a major band ( 17-19 kD) of protein(s) indicating resistance to tryptic digestion was left (Figure 3B). However, probably on account of imperfect denaturation (sample not boiled) an additional band of $\sim 21 \mathrm{kD}$ is also visible which is not present in the corresponding SDS-PAGE (Figure 3B). The dark blue band (formed due to complex of nonhydrolyzed gelatin and plant protein) presumably represents major proteinaceous protease inhibitor(s) of Cassia tora seed. The fraction obtained from gel filtration also displayed the same active protein(s) in activity gel (not shown). The above active protein band(s) coincide with (lane 5, Figure 3A) the range of molecular weight $(\sim 20 \mathrm{kD})$ characteristic of Kunitz type protease inhibitors [39]. Felicioli et al. stressed the potential of gelatin containing polyacrylamide gel electrophoresis in visualization of protein inhibitors [40].

\section{Antifungal activity assay}

The assessment of antifungal activity by inhibition of fungal conidia germination in potato dextrose broth $(\mathrm{PDB})$ at $24^{\text {th }} \mathrm{h}$ revealed that spore germination was moderately reduced. The $50 \mu \mathrm{l}$ of plant extract in conidial suspension resulted in inhibition of about $30 \%$ conidia in $12 \mathrm{~h}$. There was no further significant increase in inhibition of total conidial germination after $24 \mathrm{~h}$ onwards (Figure 4). Chen et al. reported rupture of $45 \%$

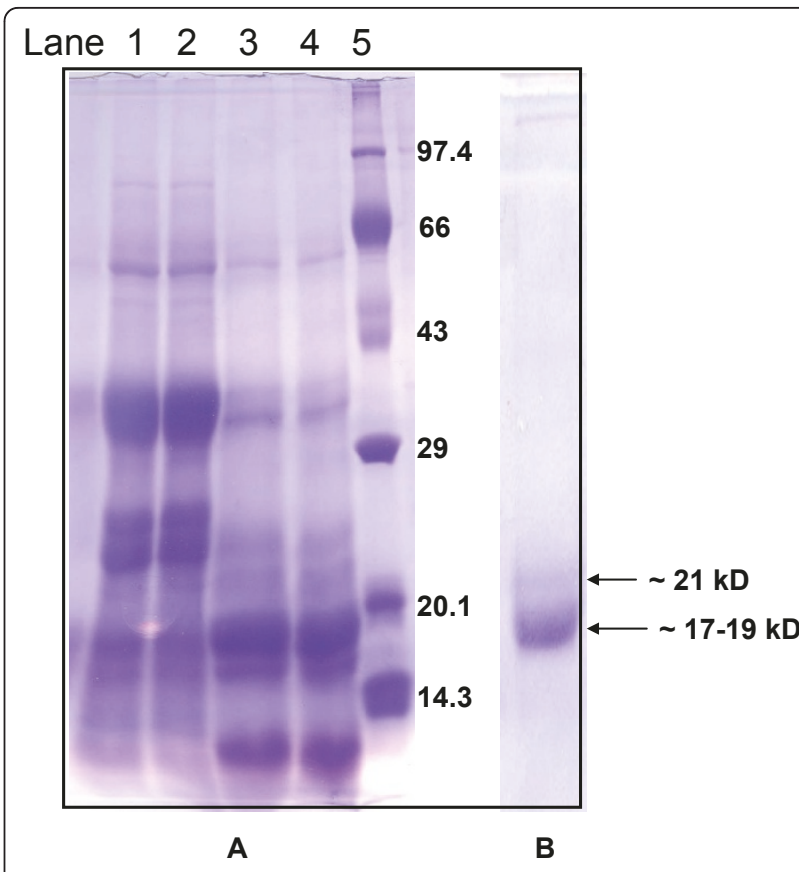

Figure 3 SDS-PAGE and Activity gel for detection of trypsin inhibitory activity of plant extract. Denaturing gel electrophoresis of $30-60 \%$ dialyzed seed extract contain many proteins of different sizes (lanes 1\& 2); active fraction pooled after size exclusion chromatography (SEC) (lanes 3 \& 4); lane 5, molecular weight marker (Fig. 3A). In activity gel, a major band ( 17-19 kD) representing active trypsin inhibitor(s) is evident (Fig. 3B).

Aspergillus flavus conidia upon incubation with $14 \mathrm{kD}$ maize trypsin inhibitor [41]. The cellular factors including proteinases produced by Aspergillus flavus may aid in germination of conidia and pathogenesis in lung alveoli cells [12]. Therefore, the proteinase inhibitors may offer relief on this account. The purified maize trypsin inhibitor simultaneously affected the growth of

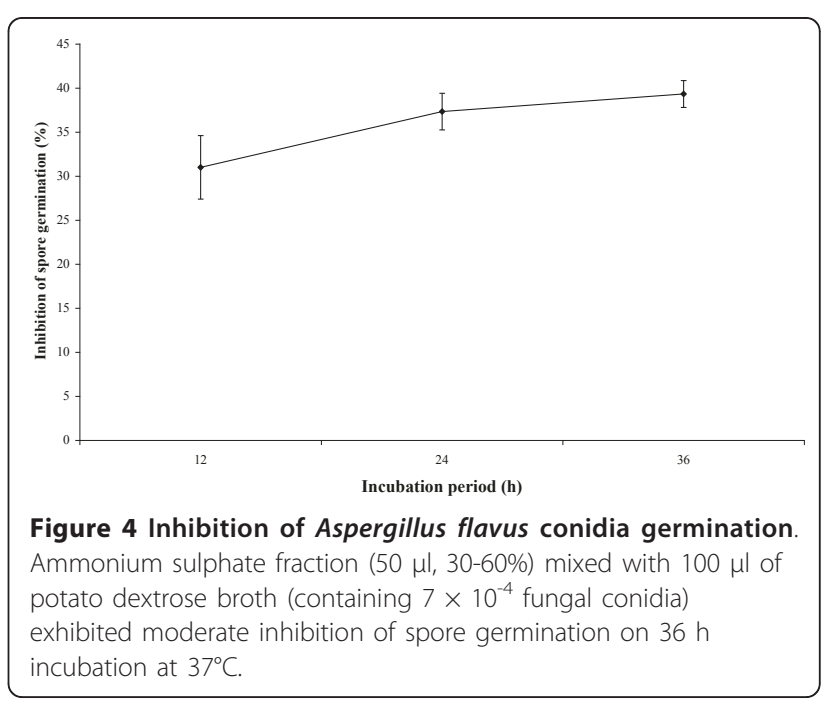


Aspergillus flavus and Fusarium moniliforme coexisting on maize plant as pathogens. Peng and Black concluded in their studies that proteinase inhibitory activity in resistant tomato plant was raised in response to infection by Phytopthora infestans [42].

\section{Conclusions}

The results revealed an unreported protease inhibitory activity in Cassia tora seeds. Traditionally, the plant is recommended in skin and gastrointestinal disorders. Inhibition of trypsin, bacterial and fungal proteases is indicative of its possible mechanism for varied therapeutic applications. The denaturing and activity gel electrophoresis revealed common protein(s) present in seed responsible for anti-tryptic activity. Aspergillus flavus with potential to affect crop yield and human health by aflatoxins can be attenuated by employing virulence attenuators like protease inhibitors. The Cassia tora seed extract moderately inhibited the spore germination of Aspergillus flavus. This can also be effectively used to bolster the plant defense response by employing biotechnological techniques in crop protection.

\section{Acknowledgements \\ Authors are thankful to Mr. Sanjay Kumar Singh (Research Scholar in department) for vital assistance and Dr. SS Mishra (Department of Mathematics and Statistics, Dr. Ram Manohar Lohia Avadh University, Faizabad) for statistical analysis. The facilities rendered to the department under the support of Department of Science \& Technology, Government of India, New Delhi (FIST programme) and Uttar Pradesh Government, under Centre of Excellence scheme is thankfully acknowledged.}

\section{Authors' contributions}

VRT carried out the isolation, spot test, caseinolytic and electrophoretic studies. SK designed and participated in antifungal activity assay. VRT and SK drafted the manuscript. SKG coordinated the design of work, revised the manuscript critically. All authors read and approved the final manuscript.

\section{Competing interests}

The authors declare that they have no competing interests.

Received: 29 November 2010 Accepted: 12 July 2011

Published: 12 July 2011

\section{References}

1. Supuran CT, Scozzafava A, Clare BW: Bacterial protease inhibitors. Med Res Rev 2002, 22(4):329-372.

2. Huynh QK, Borgmeyer JR, Zobel JF: Isolation and characterization of a 22 $\mathrm{kDa}$ protein with antifungal properties from maize seeds. Biochem Biophys Res Commun 1992, 182(1):1-5.

3. Oliva MLV, Sampaio MU: Action of plant proteinase inhibitors on enzymes of physiopathological importance. An Acad Bras Cienc 2009, 81(3):615-621.

4. National Institute of Science Communication and Information Resources (CSIR): In Wealth of India (Ca-Ci). Volume 3. New Delhi; 1992:368-370.

5. Birk Y: Plant Protease Inhibitors: Significance in Nutrition, Plant Protection, Cancer Prevention and Genetic Engineering. New York: Sprienger Verlag Berlin Heidelberg; 2003.

6. Mickel CE, Standish J: Susceptibility of processed soy flour and soy grits in storage to attack by Tribolium castaneum. University of Minnesota Agricultural Experimental Station Technical Bulletin 1947, 178:1-20.

7. Lipke H, Fraenkel GS, Liener I: Effect of soybean inhibitors on growth of Tribolium confusum. J Sci Food Agri 1954, 2:410-415.
8. Hilder VA, Gatehouse AMR, Sheerman SE, Barker RF, Boulter D: A novel mechanism of insect resistance engineered into tobacco. Nature 1987, 330:160-163.

9. Ryan CA: Proteinase inhibitors in plants: genes for improving defenses against insects and pathogens. Ann Rev Phytopathol 1990, 28:425-449.

10. Richardson MJ: Seed storage proteins: The enzyme inhibitors. In Methods in Plant Biochemistry. Edited by: Richardson MJ. New York: Academic Press; 1991:259-305.

11. Campbell CK: Forms of Aspergillosis. In The Genus Aspergillus: From taxonomy and genetics to industrial application. Edited by: Powell KA, Renwick A, Peberdy JF. New York: Plenum; 1994:313-320.

12. Krishnan S, Manavathu EK, Chandrasekar PH: Aspergillus flavus: an emerging non-fumigatus Aspergillus species of significance. Mycoses 2009, 52(3):206-222.

13. Leger RJSt, Screen SE, Shams-Pirzadeh B: Lack of host specialization in Aspergillus flavus. Appl Environ Microbiol 2000, 66:320-324.

14. Mellon JE, Cotty PJ: Expression of elastinolytic activity among isolates in Aspergillus section Flavi. Mycopathologia 1995, 131:115-120.

15. Cotty PJ, Bayman P, Egel DS, Elias KS: Agriculture, aflatoxins and Aspergillus. In The Genus Aspergillus: From taxonomy and genetics to industrial application. Edited by: Powell KA, Renwick A, Peberdy JF. New York: Plenum; 1994:1-27.

16. Hedayati MT, Pasqualotto AC, Warn PA, Bowyer P, Denning DW: Aspergillus flavus: human pathogen, allergen and mycotoxin producer. Microbiology 2007, 153:1677-1692.

17. Ivanova N, Sorokin A, Anderson I, Galleron N, Candelon B, Kapatral V, Bhattacharyya A, Reznik G, Mikhailova N, Lapidus A, Chu L, Mazur M, Goltsman E, Larsen N, D'Souza M, Walunas T, Grechkin Y, Pusch G, Haselkorn R, Fonstein M, Ehrlich SD, Overbeek R, Kyrpides N: Genome sequence of Bacillus cereus and comparative analysis with Bacillus anthracis. Nature 2003, 423:87-91.

18. Granum PE, Lund T: Bacillus cereus and its food poisoning toxins. FEMS Microbiol Lett 1997, 177:225-229.

19. Lequin MH, Vermeulen JR, van Elburg RM, Barkhof F, Kornelisse RF, Swarte R, Govaert PP: Bacillus cereus meningoencephalitis in preterm infants: neuroimaging characteristics. Am J Neuroradiol 2005, 26(8):2137-2143.

20. Ramadan RT, Ramirez R, Novosad BD, Callegan MC: Acute inflammation and loss of retinal architecture and function during experimental Bacillus endophthalmitis. Curr Eye Res 2006, 31(11):955-965.

21. Kotiranta A, Lounatmaa K, Haapasalo M: Epidemiology and pathogenesis of Bacillus cereus infections. Microbes and Infection 2000, 2(2):189-198.

22. Mulimani VH, Kulkarni S, Giri AP: Detection of legume protease inhibitors by the gel x-ray film contact print technique. Biochem Mol Bio Edu 2002, 30(1):40-44.

23. Anson ML: The estimation of pepsin, trypsin, papain, and cathepsin with hemoglobin. J Gen Physiol 1938, 22(1):79-89.

24. Lowry $\mathrm{OH}$, Rosebrough NJ, Farr AL, Randall RJ: Protein measurement with the Folin phenol reagent. J Biol Chem 1951, 193(1):265-275.

25. Creig RN, Halt GK: In Bergey's Manual of Systematic Bacteriology. Volume 1. London: Williams and Wilkins; 1984.

26. Singh SK, Tripathi VR, Jain RK, Vikram S, Garg SK: An antibiotic, heavy metal resistant and halotolerant Bacillus cereus SIU1 and its thermoalkaline protease. Microbial Cell Factories 2010, 9:59.

27. Brock FM, Forsberg CW, Buchanan-Smith JG: Proteolytic activity of rumen microorganisms and effects of proteinase inhibitors. Appl Environ Microbiol 1982, 44(3):561-569.

28. Laemmli UK: Cleavage of structural proteins during the assembly of the head of bacteriophage T4. Nature 1970, 227(5259):680-685.

29. Hanspal JS, Bushell GR, Ghosh P: Detection of protease inhibitors using substrate-containing sodium dodecyl sulfate-polyacrylamide gel electrophoresis. Anal Biochem 1983, 132(2):288-293.

30. Cheung AL, Ying P, Fischetti VA: A method to detect proteinase activity using unprocessed x-ray films. Anal Biochem 1991, 193(1):20-23.

31. Gallagher SR, Carroll EJ Jr, Leonard RT: A sensitive diffusion plate assay for screening inhibitors of protease activity in plant cell fractions. Plant Physiol 1986, 81(3):869-874.

32. Azarkan M, Dibiani R, Goormaghtigh E, Raussens V, Baeyens-Volant D: The papaya Kunitz -type trypsin inhibitor is a highly stable beta-sheet glycoprotein. Biochem Biophys Acta 2006, 1764(6):1063-1072. 
33. Lopes JLS, Valadares NF, Moraes DI, Rosa JC, Araujo HSS, Beltramini LM: Physio-chemical and antifungal properties of protease inhibitors from Acacia plumosa. Phytochemisry 2009, 70:871-879.

34. Pando SC, Oliva MLV, Sampaio CAM, Ciero LD, Novello JC, Marangoni S: Primary sequence determination of a Kunitz inhibitor isolated from Delonix regia seeds. Phytochemistry 2001, 57:625-631.

35. Bhattacharya A, Babu CR: Purification and biochemical characterization of a serine proteinase inhibitor from Derris trifoliata Lour. Seed: Insight into structural and antimalarial features. Phytochemistry 2009, 70:703-712.

36. Baker RL, Brown RL, Chen ZY, Cleveland TE, Fakhoury AM: A Maize trypsin inhibitor (ZmTlp) with limited activity against Aspergillus flavus. J Food Prot 2009, 72(1):185-188.

37. Chen ZY, Brown RL, Lax AR, Guo BZ, Cleveland TE, Russin JS: Resistance to Aspergillus flavus in corn kernels is associated with a 14-kDa protein. Phytopathology 1998, 88(4):276-281.

38. González-Lamothe R, Mitchell G, Gattuso M, Diarra MS, Malouin F, Bouarab K: Plant antimicrobial agents and their effects on plant and human pathogens. Int J Mol Sci 2009, 10(8):3400-3419.

39. Kunitz M: Crystalline soybean trypsin II inhibitor. General properties. J Gen Physiol 1947, 30(4):291-307.

40. Feliocioli R, Garzelli B, Vaccari L, Melfi D, Balestreri E: Activity staining of protein inhibitors of proteases on gelatin-containing polyacrylamide gel electrophoresis. Anal Biochem 1997, 244(1):176-179.

41. Chen ZY, Brown RL, Lax AR, Cleveland TE, Russin JS: Inhibition of plantpathogenic fungi by a corn trypsin inhibitor overexpressed in Escherichia coli. Appl Environ Microbiol 1999, 65(3):1320-1324.

42. Peng JH, Black LL: Increased proteinase inhibitor activity in response to infection of resistant tomato plant by Phytopthora infestans. Phytopathology 1976, 66:958-963.

\section{Pre-publication history}

The pre-publication history for this paper can be accessed here: http://www.biomedcentral.com/1472-6882/11/56/prepub

doi:10.1186/1472-6882-11-56

Cite this article as: Tripathi et al:: A study on trypsin, Aspergillus flavus and Bacillus sp. protease inhibitory activity in Cassia tora (L.) syn Senna tora (L.) Roxb. seed extract. BMC Complementary and Alternative Medicine 2011 11:56.

\section{Submit your next manuscript to BioMed Central and take full advantage of:}

- Convenient online submission

- Thorough peer review

- No space constraints or color figure charges

- Immediate publication on acceptance

- Inclusion in PubMed, CAS, Scopus and Google Scholar

- Research which is freely available for redistribution

Submit your manuscript at www.biomedcentral.com/submit 